\title{
Rethinking curriculum as imagined childhoods ${ }^{*}$
}

\section{Müfredatın muhayyel çocukluk olarak yeniden düşünülmesi}

\section{Article History}

Received : 01 February 2018

Revised : 08 February 2018

Accepted : 09 February 2018

Article Type

Review Article

Makale Geçmişi

Geliş : 01 Şubat 2018

Düzeltme : 08 Şubat 2018

Kabul : 09 Subat 2018

Makale Türü

Derleme Makale

\author{
Rebecca S. New ${ }^{1}$
}

\begin{abstract}
This paper proposes a reconceptualization of an early childhood curriculum as an imagined childhood such that children's early childhood education is linked to, rather than separated from, families and communities. Drawing on research by psychological anthropologists in cultures as diverse as Italy, Norway, China and Japan, the concept of cultural models is used to explain cultural differences in parenting and early childhood education. Globalization consequences, including changing national goals, dramatic population shifts, and research on immigrant parenting are used to highlight the possibilities of cultural change. The sort of change envisioned here requires ongoing intentional and inclusive deliberations involving teachers, families and community members who imagine and negotiate better ways to care for and educate their young children. Examples from the municipal services of Reggio Emilia and other Italian communities are used to highlight the array of possibilities available when adult relationships are prioritized along with those among children. Examples of recent research by Turkish scholars is used to highlight the possibilities of change and collaboration in Turkey.
\end{abstract}

Keywords: Globalization and early childhood curriculum, cultural models of child development and early education, home-school-community relations

Öz: $\mathrm{Bu}$ çalışma, erken çocukluk müfredatının, erken çocukluk eğitiminin, ailelerden ve topluluklardan ayrı olarak değil, onlarla bağlantılı olduğu şeklindeki muhayyel çocukluk olarak yeniden kavramsallaştırılmasını önermektedir. Psikolojik antropologların İtalya, Norveç, Çin ve Japonya gibi farklı kültürlerdeki araştırmalarına dayanarak, ebeveynlik ve erken çocukluk eğitimindeki kültürel farklılıkları açıklamak için kültürel modeller kavramı kullanılmıştır. Değişen ulusal hedefler, dramatik nüfus değişimleri ve göçmen ebeveynliğiyle ilgili araştırmalar da dahil olmak üzere küreselleşmenin sonuçları, kültürel değişim olasılığını vurgulamak için kullanılmıştır. Burada öngörülen değişim, küçük çocukların bakım ve eğitmenin daha iyi yollarını hayal ve müzakere eden öğretmenler, aileler ve topluluk üyelerini içeren süregelen kasıtlı ve kapsayıcı müzakereleri gerektirir. Reggio Emilia ve diğer İtalyan topluluklarının belediye hizmetlerinden örnekler, yetişkin ilişkileri çocuklarla birlikte öncelikli olduğunda olasılıklar dizisini vurgulamak için kullanılmıştır. Türk araştırmacılar tarafından yapılan son araştırmaların örnekleri, Türkiye'de değişim ve işbirliği olanaklarını vurgulamak için kullanılmıştır.

Anahtar Kelimeler: Küreselleşme ve okul öncesi eğitim, çocuk gelişimi ve erken eğitim kültürel modelleri, okul-aile-toplum ilişkileri

\footnotetext{
*Presented as "Keynote Speech" at $5^{\text {th }}$ International Early Childhood Education Congress

${ }^{1}$ University of North Carolina at Chapel Hill, rebecca.new@unc.edu
} 


\section{INTRODUCTION}

I was delighted to receive the invitation to speak at this conference celebrating Turkey's commitment to increasing and improving early childhood services for children and families. That commitment is evidenced by the many teachers, researchers and teacher educators in attendance. I look forward to my time with you and the other speakers.

This year's conference theme- "Strong Start for Every Child: Cultural Diversity and Inclusive Education in Early Childhood"-is a familiar mission imbued with a new sense of urgency given the rapid pace of changes in societies around the world. Few would disagree with a key mission shared by early childhood professionals: to generate and use new knowledge on behalf of young children. This mission is also accompanied by a challenge that is decades old: to determine what qualifies as reliable and valid knowledge to inform our work with children and families - an uncertainty that is surprising, given that the long history of research on early learning and development. Debates about what constitutes useful science are increasingly accompanied by other doubts about what it means for us to 'do better' in supporting children and families. Decades of research by early childhood scholars in nations as diverse as China, Italy, Japan and Senegal1 provides compelling alternative interpretations of what is and is not 'developmentally appropriate' (Mallory \& New, 1994; New, 2003); this work defies the scientific rationale of NAEYC2 guidelines, revised and disseminated over the past three decades to millions of educators world-wide (Bredekamp, 1987; Bredekamp \& Copple, 1997; 2009).

Other sources of uncertainty as to how best to direct our field's efforts are surfacing in no small part due to the increasingly globalized and multicultural contexts in which children are growing up. Early childhood researchers in the U.S. no longer need to travel to other countries to experience cultural differences. Current census data and population surveys calculate that children of immigrant and refugee households now represent approximately $27 \%$ of the total U.S. population, or $26 \%$ of the population of children under age 18 . Countries of origin of those immigrants who have obtained legal permanent residence status include, in order of size of immigrant population, Mexico (15\%), China (7\%), India (6\%); the Philippines, Cuba and the Dominican Republic (5\%); Vietnam (3\%); and Iraq, El Salvador, and Pakistan (2\% each). The Diversity Visa Lottery (established in 1990) and the Nicaraguan and Central American Relief Act of 1997 have contributed to the population growth as well as the diversity of immigrants,

\footnotetext{
${ }^{1}$ See, for example, references to Mimi Bloch, Sally Lubeck, Carolyn Edwards and Joe Tobin

${ }^{2}$ The U.S.-based National Association for the Education of Young Children. 
in terms of cultural traditions, education and language of origin, who are now residing legally in the U.S (Zong, Jie \& Batalova, Jeanne. (2017). In spite of their legal status, these immigrants along with an unknown number of undocumented immigrants and refugees, are subject to increasingly hostile discourses. Other nations with vastly larger numbers of immigrants and refugees also struggle with the ethical and pragmatic challenges of welcoming

In industrialized nations around the world, rapid population changes are accompanied by a globalized press for standardized measures of achievement and a narrowing of the early childhood curriculum at the expense of children's creativity, play and socio-emotional development (Nitecki \& Wasmuth, 2017). 1 In the U.S., early care and education services continue to interpret "diversity" as reasons to divide children, whether as a function of language, developmental differences, or socio-economic status home-school-community relations in Italian early childhood education. Public school reform initiatives highlight evidence-based "best" practices and mandated curricula at the expense of teacher-initiated pedagogies more responsive to children's particular interests, needs and capabilities. Such contested interpretations of what is meant by an early childhood education represent high-stake challenges; they also present new opportunities for the international ECE community. In other words, how could we capitalize on the increasing globalization of early childhood education to more collaboratively and effectively address the challenges posed by the conference theme?

In the pages that follow, I will outline a new way of thinking about an early childhood curriculum responsive to these challenges-- by re-conceptualizing the task as one of imagining and designing a childhood for children where they currently live. This re-conceptualization is based on the premise that an early childhood curriculum is nothing less than a major social responsibility given its influence on children's lives; as such, I am purposefully resisting traditional interpretations of curriculum sources, goals and foci. This proposition also requires us to set aside our current habits of mind. Put another way, this approach to curriculum as

\section{imagined childhood}

- requires us to question taken-for-granted professional knowledge;

- insists that we consider the full complexity and socio-cultural contexts of children's lives, outside as well as within the classroom; and

\footnotetext{
${ }^{1}$ For a more thorough discussion and critique of global trends in early childhood education, see the full special issue on Global Trends in Early Childhood, published in Global Education Review 
- necessitates the inclusion of diverse points of view as represented by families, community members -and each other.

My goal for the remainder of this paper is to persuade you that this combination of curiosity, doubt, and an openness to diverse points of view can lead to more of what we claim to seek.

\section{Scientific images of children, teachers and the period of early childhood}

The history of early care and education in the U.S. is premised on an image of teachers and caregivers as professionals based on the field's scientific knowledge base (Bloch, 1991). Although this scientific knowledge has long been critiqued as child development researchers continue to engage in three broad categories of inquiry: (1) child development and parenting in relation to race, ethnicity and socioeconomic status (c.f., Barbarin, Early, Clifford, Bryant, Frome, Burchinal \& Pianta, 2008); Hagen \& Conley, 1994); (2) forty years of research on potential negative outcomes of early child care (Belsky \& Steinberg, 1978; Belsky et al, 2007; NICHD Early Child Care Research Network, 2018); and the lasting effects, including child outcomes and economic benefits, of high quality preschool programs (Consortium for Longitudinal Studies, 1983; Head Start Bureau, 2000). In part due to the ethnocentric and reductionist measures used in many of these studies, this research has been critiqued as providing rationale for institutional racism (Baratz \& Baratz, 1970) and have sustained a century of theories in defense of segregated programs (New \& Mallory, 1996), including parent education programs for low-income families whose lifestyles are viewed through deficit lens (Lubeck, 2001). What this research has not managed to do is reduce the chronic poverty in the US (Harrington, 1962; Lareau, 2003) or generate the political will for publically funded child care for infants and toddlers (Lally, 2013). And yet the increasingly public perception acknowledges the early years as a critical time in children's development. In turn, private and public pre-kindergarten programs, pediatricians, parenting magazines and toy manufacturers espouse the importance of scientifically-based 'developmentally appropriate' toys and teaching practice (i.e., Bredekamp, 1987; Bredekamp \& Copple, 1997). Yet research is not the only driver of these professional views of what is, and is not, appropriate. Recent interpretations of "DAP" (Copple \& Bredekamp, 2009) reflect growing neo-liberal and accountability arguments for early teaching and assessment of pre-academic skills such as literacy and mathematics (Heckman, 2006).

\section{Cultural models of child development.}


I have long been intrigued with cultural images of children and families, which is what led me to Italy many decades ago for a study of Italian parental goals and infant care (New, 1988). This year-long study persuaded me of the ethnocentric bias of a knowledge base I had previously embraced as a teacher and scholar. Also central to my critique of our field's reliance on a century of Western [ne, American] social science were my personal experiences as a new parent, as I learned from the 'subjects' of my research new ways to help a fussy baby manage teething and learn how to walk, and the importance of joining the rest of the family at the family dinner table (New, 2001). Much of what I thought was essential for my child was set aside as we learned how to participate in our new Italian community.

At the time, I understand that this was a unique opportunity for me and my family, one that isn't likely to be shared by most even as families with young children now travel around the world, whether by choice or necessity. For those of you with less direct experience with cultural incongruities, I invite you to consider what you would seek as an ideal childhood for your own children; and how your ideas (ideals) might vary from those of your neighbors. Would you allow them to climb tall trees and play outside in the rain? What time would young children go to bed? Would you want them to learn that they are unique in the world, or that they are "not so special"? What languages would be spoken and encouraged in this childhood setting? Would socialization practices include frequent praise and rewards, or physical punishment, or public shaming? Who would flourish in your imaginary childhood? Who would be considered a minority? In my visits to nations around the world, adults give widely different responses to questions such as these (New, 1999). Since that formative experience, I've joined other psychological anthropologists in an effort to examine and make sense of cultural differences in terms of "sensitive parenting,' a "good child" and "appropriate" early childhood education.

Decades of research on cultural models of child development, including studies of parenting traditions as well as cross-national comparisons of early care and education, highlight the important roles of history and environmental demands on cultural values, beliefs and goals (LeVine \& New, 2008). Such cultural ideologies or ethnotheories (Harkness \& Super, 1996) are not limited to interpretations of what and how children learn and develop. Ample research illustrates the multiple ways in which cultural belief systems are instantiated in cultural routines, traditions and accompanying discourses. These practices, in turn, are aligned with moral imperatives directed to the nurturing of culturally specific virtues (Li, 2012). Anthropologists' efforts to illuminate the visible and ideological dimensions of culture traditionally rely on ethnographic methods, arguably "the most important" means of understanding human 
development (Weisner, 1996). Research on the cultural nature of child development (Rogoff, 2003) has also benefitted from the concept of a "developmental niche" as delineated by anthropologists Sara Harkness and Charles Super $(1983$; 1986). Used primarily in studies of children's home environments, the niche concept highlights social and physical characteristics of the environment, normative patterns of interaction, and ideologies of those in charge. These attributes are also applicable to the study of early childhood settings. Consider, for example, differences in the physical and social settings of a Norwegian barnhagen and a US kindergarten.

The Norwegian barnhagen is available to all children residing in Norway, beginning at age one, and children may be grouped for at least part of the day in mixed-age settings. Children spend much of their time out-of-doors, even in inclement weather, climbing trees or boulders as part of a national commitment to fostering a love of the natural environment. Teachers come to work dressed in clothing suitable to these outdoor activities and they frequently join children in their outside adventures. Inside, older children may help younger ones with snow suits or puzzles; and classrooms are decorated with images of Norwegian artists and children's art projects. In the US kindergarten, out-door play may be as brief as a 20-minute recess in a prescribed area where activities are limited to those that are 'risk-free.' Teachers rarely engage in children's outdoor play, and no one is allowed to climb a tree or scramble over a boulder out of sight of adults. Inside, a major portion of the classroom is arranged in small 'activity' settings with signs indicating the number of children allowed. Licensure regulations make it difficult if not impossible for older children to share spaces with younger ones. The walls in US kindergarten classrooms are typically filled with the alphabet, a calendar, and children's work samples. In each case, these school settings can be distinguished by culturally sanctioned physical and social characteristics and patterns of interaction between adults and children.

Those visible features are manifestations of the 'psychology' of the adults in terms of the cultural values and goals represented in an early childhood education. Thus Norwegian early childhood guidelines emphasize children's rights to actively explore the environment, play together and actively participate in decision making as central to the promotion of gender equity and a socially just society (Einarsdottir \& Wagner, 2006). U.S. educators, in contrast, are more likely to highlight children's pre-academic abilities, linguistic and pro-social skills, selfregulation and autonomy in terms of self-care - educational goals aligned with cultural values of independence and school achievement. In each nation, visible and ideological features of the developmental niche constitute the interface between culture and child development. The alignment of cultural contexts, including resources and socialization practices, with child 
characteristics that are nurtured in these cultural settings was not lost on one developmental psychologist who described ("an American) childhood as a cultural invention" (Kessen, 1979).

Ethnographic research on the cultural dimensions of children's home and school environments highlights another aspect of children's learning and development too often ignored by developmental researchers or early childhood educators: children participate in multiple cultural worlds, not just one bounded by four walls or a fence. The reality of children's lives is belied by a research focus on any one setting - most often the home or the classroom - at the expense of others that also contribute to children's early learning: the neighborhood, the church, the market, the grandmother's home. In each setting, children have access to resources [human and material] and messages about who they are, what behaviors are permitted, what types of skills and understandings are most useful or necessary. This interpretation of childhood includes ongoing and often daily occasions in which children (attempt to) participate in communal settings and make sense of multiple ways of being. An early childhood curriculum that ignores such experiences beyond the classroom door is ignorant of what is most central to the child herself-her life as she lives it. I turn to Italy for inspiration, given that culture's insistence on the inextricable relationship between children, their families and the communities in which they live, learn and develop.

\section{Cultural images of children, parents, and teachers: Italy as case study.}

An Italian early childhood education cannot be adequately described in a brief paper or conference presentation, yet key features illustrate that nation's cultural model as it informs early childhood practices and home-school relations (New, Mallory, \& Mantovani, 2000). National policies established in 1968 and 1971 outline children's rights to high quality early care and education; families' rights to be involved in those experiences, including children's transitions to out-of-home early child settings; and community responsibilities for establishing early childhood services not only as spaces for children but also as laboratories for adult learning and professional development1. These long-standing Italian cultural values, including the benefits of enduring relationships, collaboration and pride in local traditions, are evident in normative educational practices and national policies that have emerged over the last half century.

\footnotetext{
${ }^{1}$ Italian laws about teachers' professional development mandated this view of 'schools for young children [early childhood and elementary] as 'laboratories for teachers' with community-based documentation centers where teachers could share their materials and curriculum plans. It was not until 2000 that a new law was passed mandating a university degree as a pre-service requirement for teachers of young and schoolage children. The particulars of that law continue to be debated and revised. 
Italian educators seek ways to establish trusting relationships with family members beginning during the first "delicate moment" of l'inserimento, as educators and parents work closely together to ease both children and adults through the transition from the home to the early childhood setting (Bove, 1999). Transition processes set the stage for more genuine and reciprocal relationships with family members that continue to develop over time. Organizational norms support those relationships, as groups of children and their (2) teachers remain together for the duration of time in the educational setting. Thus, families of infants and toddlers in the asilo nido have three years to get to know one another; and they share another three years in the 'preschool' settings for 3- to 5-year olds. Elementary schools share the same tradition; children and adults [parents \& teachers] remain with the same group for five years. These common practices instantiate the cultural value of relationships and are evident throughout Italy, even as ECE services require community support and draw on local traditions and regional resources.

\section{Reggio Emilia as a special case of Italian ECE}

The city of Reggio Emilia is surely the best known of Italy's municipal early childhood services, thanks to a series of traveling exhibitions that, beginning in the late 1970's, traveled throughout Western Europe and eventually to every continent in the world (New, 1990). Carefully designed displays of children's multiple (one hundred!) symbolic languages and long-term projects [progettazione] have confounded some observers and inspired others to reflect on this compelling interpretation of an early childhood curriculum. Other characteristics of what most refer to as the "Reggio Emilia Approach" (Edwards, Gandini \& Forman, 1993, 1997, 2009) include an adult-friendly environment and the use of documentation to make children's learning experiences more accessible to families and members of the community.

A prepared environment that provokes. Reggio Emilia's early childhood environments are not only designed for children; they also function as provocative contexts for adult learning, with foyers and hallways filled with photographs and documentation of children's project work. Areas that function as piazzas and play spaces within the classroom include resources from children's homes and the larger community. Arrangements of the physical environment invite new questions - e.g., is it safe for children to climb up so high? - and sometimes prolonged discussions about children's rights to test their developing abilities. Throughout, the intentionally positioned documentation helps to explain the rationale and goals of children's project work to parents (and thousands of visitors) and advocates for an image of teachers as researchers (New, 1998). These features are critical to the reputation of this city's early 
childhood services, given their success at attracting and engaging the attention of adults (New $\&$ Mallory, 2005). They also have much to offer to our deliberations of an early childhood curriculum that is connected to children's family lives and the larger community.

An enhanced interpretation of home-school-community relations. As is the case throughout Italy, Reggio Emilia's philosophy of early care and education is premised on the importance of relationships. This cultural priority is supported in Reggio Emilia in ways that go beyond l'inserimento practices to include class meetings, serate nella cucina [evenings in the kitchen], parties for grandparents, school-wide initiatives, and as well as citywide celebrations-all vehicles to bring parents and community members together. Children and teachers make frequent excursions into city spaces, and their presence is a compelling reminder to community leaders of the city's responsibilities to their youngest citizens. Although adult conversations inspired by such occasions inevitably focus on the children, the relationships that develop within and outside the school setting also contribute to adult lives and a strong sense of community among its citizens. This interpretation of home-school-community relationships is akin to the Italian concept of civic engagement, aka partecipazione. Reggio Emilia's deliberate efforts to promote parent and community 'involvement' as a civic responsibility has contributed to the city's success in maintaining and expanding their early childhood services to include spaces for the growing number of children of immigrant and refugee families, once again demonstrating that a community of adults - only some of whom are educators - can collaboratively and productively contribute to an early childhood education that is worthy of children - and the name of the community itself (New \& Kantor, 2013).

Research with colleagues in other Italian communities reveal other interpretations of quality early care and education that resonate with Italian cultural values of collaboration and civic engagement. In defiance of cultural stereotyping, Italy's diverse municipal programs and curriculum decisions illustrate the dynamic nature of cultural practices as a function of regional differences, community resources and shared decision-making. For example, Milan's early childhood services are organized according to dozens of 'neighborhood' areas throughout the city. In one such neighborhood scuola dell'infanzia, children whose families worked in banks and towering office buildings sought help from teachers and family members to create spaces in the form of a pizzeria, bakery and small office spaces with cardboard box "computers" as more meaningful places for play that echoed the large urban environment. In the small hilltown of San Miniato, community members concerned about the number of children without siblings argued successfully for an array of mixed-age services for infants and toddlers such that they 
could have 'sibling-like' relationships traditionally found in the home. Thus four-month-old infants were together with children as old as three years. In an impoverished neighborhood in Naples, a new state-funded preschool remained empty until teachers surveyed local grandparents, many of whom had discouraged enrollment of their grandchildren due to fears that the children would be 'robbed' of their cultural heritage in the preschool. After lengthy deliberation, the teachers invited grandparents to assist in a curriculum focused on indigenous cultural practices they considered most essential to share with three-, four- and five-year olds. Thus the children and adults brought the grape harvest, including the tools and raw materials, into the classroom, where the grandparents taught the children the proper ways to stomp the grapes. The children bottled the liquid and made labels that proudly proclaimed the D.O.C. [official determination of origin]. I'm hard pressed to think of a better example of an early childhood curriculum that is inextricable from childhood.

What is common across these diverse Italian settings is the power of children as catalysts for adult conversations (New \& Mallory, 2005); and the potentials of adults to collaborate in designing curriculum that is part of, rather than separate from, their lives in the community.

\section{Cultural models in transition}

This research, my own and others, problematizes any singular notion of a good childhood and underscores the cultural nature of human development. But these descriptions of the historic roots of cultural values and practices, the prospects of change seem less optimistic. Yet Loris Malaguzzi was clear in his charge that we must "change the culture of childhood "(1993); and few of us are satisfied with the status quo. So whether than debate about whether change is possible, I take heart in some of the changes already taking place at the local, national and international levels.

Globalization provides both incentive and evidence for the potentials of cultural changes in how children are cared for and education (O.E.C.D., 2001, 2006). Joe Tobin's international comparison of preschools in Japan, China and the U.S. helps to explain some of those changes over a 20-year-span. Through multi-vocal video ethnographies, the initial research described cultural values and traditions at odds among the three nations (Tobin, Wu, \& Davidson, 1989). The follow-up study highlights both change and continuities, as teachers within the three cultural settings have, over time, rejected some traditional practices and on occasion borrowed from one another in order to achieve changing national goals (Tobin, Hsueh \& Karasawa, 2009). For example, changes in the 'typical' U.S. classroom to an increased emphasis on preacademic skills reflected increasing national concerns about international achievement test 
rankings. Changes in China's national priorities, in contrast, reveal a clear shift away from teacher-directed and whole group instruction to a play-based curriculum with time for art and other creative activities. My own observations support these findings, albeit with influences other than government mandates. In my visits to private early childhood programs in Beijing and Shanghai, Western brand name approaches (Roopnarine \& Johnson, 2013)1 are often used to label different kindergarten classrooms. In one Shanghai preschool, the director described a visit to Reggio Emilia before proudly giving a tour of her school. Teachers' interpretations of children's 'symbolic languages' were evident in a series of spaces for large-scale construction activities; another room was dedicated to an ongoing project on ancient Ming dynasty pottery, in which children researched and created their own designs first through drawing, then painting, and eventually as ceramics fired in a local kiln.

Governments, international competitions, and inspired program directors are not the only impetus for and evidence of intentional changes in traditional cultural models of early childhood education. Millions of immigrant adults have determined to raise their children in settings far removed from their cultural origins. In our ongoing longitudinal study of Chinese and Latinx immigrant parenting, Chinese and Latinx parents describe their decision to move to the US based on a conviction that their children will benefit from the American culture's educational model. As their hopes come up against the realities of children's early transitions from home to school, these same adults describe uncertainties amid ongoing negotiations with family members through transnational exchanges about the efficacy of their traditional cultural practices and those deemed necessary to children's success in U.S. schools. They also describe struggles to understand and accommodate to changing expectations of their roles, e.g. in terms of children's school readiness, homework or the 'appropriate' levels of parent involvement. Language confusions ["Open house..? Casa aperta? Is the teacher coming to our house?] and generational conflicts [ 'it is ok if my daughter tells me 'no' but it makes my mother-in-law(who is living with us now) very angry"'] are common, yet most parents in our study remain open to and accepting of new ways of relating to their children and supporting their early schooling. That's not to say that they have entirely left behind their traditional cultural models of learning. Some traditional beliefs, such as their high regard of teachers as figures of authority and respect, may explain why parents from both China and Mexico seem reassured when describing problematic child behavior, explaining "The teacher says it is normal at this age..". Although other aspects of our study participants' traditional models highlight their respective cultural

\footnotetext{
${ }^{1}$ E.g., Montessori, High Scope.. 
differences - eg, in the need for active school-focused learning activities in the home-families in each immigrant group express pride in their children's successful transitioning from home to kindergarten and on to first grade. We know, however, from the growing body of research on immigrant children, that their future success is not guaranteed (Suarez-Orozco \& SuarezOrozco, 2005). Recent studies describe counter-intuitive findings in which immigrant children who successfully integrate into their American peer groups may be at greater risk for learning and developmental difficulties (Garcia-Coll \& Marks, 2012). Yet a vast majority of immigrant research has focused on older children and adolescents within the school setting, with few attending to the perspectives of parents within the context of immigrant family life. Thus we are far from knowing what parents, teachers and local citizens might do together to insure the continued success of all children in their multicultural communities.

So what lessons might we learn from this research in order to approach the goal announced in the theme of this conference - a Strong Start for Every Child: Cultural Diversity and Inclusive Education in Early Childhood"? If we were to take seriously the idea that an early childhood curriculum must be connected to, rather than separated from, our larger hopes for young children, then any effort to translate our hopes into action would benefit from the following qualities of a Curriculum as Imagined Childhood:

INTENTIONAL. Turkish scholar Cigdem Kagitcibasi (1996) noted another consequence of this growing knowledge of our cultural differences. To the extent that we are no longer bound to cultural traditions, we are responsible for the choices we make. This more personal notion of responsibility raises the bar on a curriculum as imagined and intentional childhood, and includes our purposeful deliberation of such practices as....

- Using standardized tests for non-standard children

- Requiring children to learn one language at the expense of their heritage language

- Prioritizing academic skills over creativity, problem-solving, emotional well-being

- Substituting "schoolification" rules in place of social competence

- Implementing a curriculum created by people who do not know our children.

INCLUSIVE. A curriculum as imagined and intentional childhoods for our increasingly diverse and globalized societies is based on an ethic of inclusion that is biased in favor of the rights and potentials of all children to learn, no matter their abilities, languages, family customs or circumstances. Such an imagined, intentional and inclusive childhood would therefore reflect the features of those societies, including the diversity of children, families and 
perspectives as found in particular local settings. As argued by Sergio Spaggiari, former director of Reggio Emilia's early childhood services, "if education is for the future, then everyone must be involved" (New, 1997). Thus early childhood professionals would redefine the concept of 'best practice' by....

- Embracing the ethic of doubt so that seeking out others and sharing ideas and experiences is seen as essential to informed and intentional teaching.

- Including in these conversations a full array of professionals, including early childhood and elementary teachers, counselors and administrators; and family members — not only mothers but also fathers and grandparents; and community member representative of minority and immigrant populations as well as business owners and elected officials, young adults and the elderly.

- Avoiding the use of globalized discourses like "DAP" and deficit labels for children to keep conversations open about what is best for these children, based on their strengths and learning goals ....in this place... at this time..

- Highlighting the value of local resources and family traditions as curriculum content, learning materials and pedagogical possibilities.

IMAGINATIVE. Collaborative and community-based efforts to imagine a new, intentional and inclusive curriculum that is part of children's larger childhood experiences requires more than a determination to make decisions informed by debate and negotiation of multiple points of view. The concept of 'imagining' is insufficient to the task of any hypothesized plan for change without the added value of remaining open to surprises as adults become more closely engaged in deliberating the very nature and contexts of children's early learning. For early childhood professionals, this imaginative quality would appear as:

- Advocacy for children's creative and critical thinking as well as their academic achievements;

- An early childhood pedagogy that includes dedicated opportunities and time for children and their teachers to experiment and explore, generate new hypotheses;

- Environments and routines that include opportunities for risk-taking and problems to solve

- Discourses that include what you don't know as motive to wonder what if.. 
- New uses of documentation and technology as resources for home-school- community communications and tools for deliberative collaborative inquiry into children's early childhoods

- Classrooms as only one type of shared space in which children and adults are partners and collaborators in the reciprocal processes of living and learning together in a world that continues to change.

\section{CONCLUSION}

I began this paper by considering the attributes of curiosity, doubt, openness to new ideas as fundamental to a reconceptualization of an early childhood curriculum. As described in this paper, a conception of curriculum as an imagined childhood has the potential, ne, has as a goal to change how we see and interpret this time of life, too often referred to as the beginning of future accomplishments rather than a time worthy of respect for its own sake. Such an image of curriculum as an imagined childhood has the potential to change how we see and 'study' children, and how we prepare new teachers for their work (New, 2015). Sustained and collaborative attention to children's actual childhood experiences pushes us to think carefully about how we conduct and use research; and to carefully consider the relevance of a generic child development knowledge base to the teaching and learning of particular children in particular places (Lubeck, 2000). My hope is that an up-close focus with "clear eyes," as urged by Beth Harry, will help us to make better decisions based on more thoughtful attention to children's interests and abilities, fears and pleasures, discoveries and questions as they emerge in the home, the larger community as well as the classroom. Such nuanced insights into children and their lives can inspire us to imagine an early childhood curriculum with more personally meaningful problems to solve with peers, and to help identify authentic responsibilities for them within the family, school and community. It also requires us take risks in order to determine what is possible (New, Mardell \& Robinson, 2005).

The most difficult part of this proposal, I'm sure, is what it requires of us in terms of our cultural and professional identities and allegiances. Why? Because to do this curriculum imagining will require all of us to seek out, carefully consider and be willing to negotiate diverse points of view - some of them from cultures we know little about, others that we are already biased against.

That's not to say that ideas and understandings don't cross borders, nor that we don't encounter some similar challenges in diverse settings. In her presentation, Maya Kalempur noted the 
risks in assuming that we can borrow practices from one culture and apply them to problems elsewhere. But pluralistic multi-cultural settings -including conferences such as these-- create occasions to intentionally share and deliberate such choices. Over the course of preparing for the conference and writing this paper, I have learned a lot about Turkey that gives me confidence in this pursuit. Research on Turkish families and the value of children as they've changed over time (Atace, Kagitcibasi \& Diri, 2005) was invaluable as a first introduction to Turkey's "social and cultural mosaic" (p. 91). This work was also essential as a backdrop to understanding changing perspectives on the importance of preschool as a place to play and learn (Irrendi \& Erdoga, 2015). These and other studies remind me of the complexity and diversity of our diversities, as Turkish scholars refer to the ongoing shifts from rural to urban places of residence, family life and socialization practices (Kagitcibasi, 2005) and intergenerational relations (Kagitcibasi, Ataca \& Diri, 2010). Such features of present day Turkey are not only relevant to Turkish initiatives in early childhood education; they also hint at the challenges of bringing diverse groups of adults together to deliberate on their goals for their children. Those challenges are already being examined in studies that document differences among and between Turkish parents and teachers about the purposes of an early childhood education (Sahin, Sak \& Sahin, 2013; Sak, 2015). As I gained insights into the vast heterogeneity of Turkish society and the recent and rapid pace of social change, I was also struck by the benefits of reading the work of Turkish scholars whose very research questions and conceptual frameworks illuminate cultural problems and priorities often invisible in more standardized approaches to research on young children. Of special relevance to this point is research by Turkish scholars on Turkish children's multiple identities as reflected in their English-language education (Atay \& Ece, 2009). These are just some of the topics of collaborative exchanges I am hoping we might continue.

I will conclude by returning to a question posed at the beginning of this paper about whether we are willing to listen and ready to learn from our diverse interpretations of children and a curriculum worthy of them (Abu-Zena \& New, 2012). Such exchanges are not easy, nor should they be, as Malaguzzi often cautioned. Yet I've no doubt, inspired in part by our field's long history of sharing across cultures, that your children, my grandchildren, all children have much to gain if we are up the challenge of capitalizing on our breadth of experience and expertise, including the funds of knowledge and passions of those who know and love them. The image of curriculum as childhood represents a cultural project that is surely among the biggest decisions a society... a community... an inclusive group of thoughtful adults can make. When 
we use our collective imaginations and pay careful attention to the children, our efforts have the potential to influence children's lives - and the quality of life in the communities where they live.

Thank you again for the opportunity to explore these ideas with you.

\section{REFERENCES}

Abu-Zena, M. \& New, R. (2012). Children are ready to learn, but are we? The role of adult relations in school readiness. Zero to Three, 33(1), 28-36.

Ataca, B., Kagitcibasi, C., \& Diri, A. (2005). The Turkish family and the value of children: Trends over time. In G. Trommsdorff \& B. Nauck, Eds., The value of children in cross-cultural perspective. Case studies from eight societies, pp. 91-119. Lengerich, Germany: Pabst Science.

Atay, D. \& Ece, A. (2009). Multiple identities as reflected in English-language education: The Turkish perspective. Journal of Language, Identity \& Education, 8(1), 21-24.

Baratz, S. S., \& Baratz, J. C. (1970). Early childhood intervention: The social science base of institutional racism. Harvard Educational Review, 40, 29-50.

Barbarin, O. A., Early, D., Clifford, R., Bryant, D., Frome, P., Burchinal, M., Pianta, R. (2008). Parental conceptions of school readiness: Relation to ethnicity, socioeconomic status, and children's skills. Early Education \& Development, 19(5), 671-701.

Belsky, J., \& Steinberg, L. D. (1978). The effects of daycare: A critical review. Child Development, 49, 929-949.

Belsky, J., Vandell, D. L., Burchinal, M., Clarke-Stewart, K. A., McCartney, K., \& Owen, M. T. (2007). Are there long-term effects of child care? Child Development, 78 (2), 681701.

Bredekamp, S. (1987). Developmentally appropriate practice in early childhood programs serving children from birth through age eight. Washington, DC: National Association for the Education of Young Children.

Bredekamp, S., \& Copple, C. (Eds.) (1997). Developmentally appropriate practice for early childhood programs serving children from birth through age eight (Rev. ed.). Washington, DC: NAEYC.

Consortium for Longitudinal Studies. (1983). As the twig is bent: Lasting effects of preschool programs. Hillsdale, NJ: Lawrence Erlbaum.

Copple, C., \& Bredekamp, S. (2009). Developmentally Appropriate Practice (in Early Childhood Programs, Serving Children from Birth through Age 8). Washington, DC: National Association for the Education of Young Children.

Edwards, C., Gandini, L. \& Forman, G. (Eds.) (1993; 1998; 2009). The hundred languages of children: the Reggio Emilia Approach to early childhood education. 1 st, $2^{\text {nd }}$ and $3^{\text {rd }}$ editions. Norwood, NJ: Ablex. 
Einarsdottir, J., \& Wagner, J.T. (2006). Nordic childhoods in early education. Greenwich,Ct: Information Age Publishing

García Coll, C. \& Marks, A. (Eds). (2012). The immigrant paradox in children and adolescents: Is becoming American a developmental risk? American Psychological Association: Washington, D.C.

Hagen, J. W., \& Conley, A. C. (1994, Spring). Ethnicity and race of children studied in Child Development, 1980-1993. SRCD Newsletter, 6-7. Los Angeles, CA: Society for Research in Child Development.

Harkness, S., \& Super, C. (Eds.). (1996). Parents' cultural belief systems: Their origins, expressions, and consequences. New York: Guilford Press.

Harrington, M. (1962). The other America-Poverty in the United States.

Head Start Bureau (2000). The Head Start Child Outcomes Framework. Washington, DC: Author. www.hsnrc.org/CDI/pdfs/UGCOF.pdf

Heckman, JU. (2006). Skill Formation and the Economics of Investing in Disadvantaged Children. SCIENCE, 312, pp. 1900-1902.

Irrendi, A. \& Erdoga, N. (2015). Play in a Turkish cultural context. In J. Roopnarine, M.M. Patte, J. Johnson, \& D. Kuschner (Eds), International perspectives on children's play. Berkshirt, UK: Open University Press.

Kagitcibasi, C. (1996). Family and human development across cultures: A view from the other side. NY: Erlbaum.

Kagitcibasi, C., Ataca, B., Diri, A. (2010). Intergenerational relationships in the family: Ethnic, socioeconomic, and country variations in Germany, Israel, Palestine, and Turkey. Journal of Cross-Cultural Psychology 41 (5-6), 652-670

Kessen, W. (1979). The American child and other cultural inventions. American Psychologist, 34(10), 815-820.

Lally, R. (2013). For our babies: Ending the invisible neglect of America's infants. NY: Teachers College Press.

Lareau, A. (2003). Unequal childhoods: Class, race, and family life. Berkeley, CA: UC Press.

LeVine, R., \& New, R. (Eds.) (2008). Anthropology and child development: Selected Readings. Malden, MA: Blackwell Publishers.

Li, J. (2012). Cultural foundations of learning: East and West. Cambridge, UK: Cambridge University Press.

Lubeck, S. (2000). On reassessing the relevance of the child development knowledge base to education: A response. Human Development, 43(4-5), 273-278.

Malaguzzi, L. (1993). History, ideas and basic philosophy. In C. Edwards, L. Gandini \& G. Forman (Eds.), The hundred languages of children: the Reggio Emilia Approach to early childhood education, pp. 41-89). Norwood, NJ: Ablex. 
Mallory, B., \& New, R. (Eds.) (1994). Diversity and developmentally appropriate practices: Challenges for early childhood education. NY: Teachers College Press.

New, R. (2015). $21^{\text {st }}$ century early childhood teacher education: New frames for a shifting landscape. In L. J. Couse \& S. L. Reschia (Eds.), Handbook of early childhood teacher education. Pp. 1 - 14. NY: Routledge.

New, R. (2010). Cross-cultural research on children's development: Deep roots and new branches. Journal of Cross-Cultural Psychology, 41: 522-533. Special issue on J. \& B. Whiting, guest editors C. Edwards and T. Weisner.

New, R. (2007). Reggio Emilia as cultural activity theory in practice. Theory into Practice, $46(1)$, pp. 5-13.

New, R. (2001). Quando c'e' figli: Observations on Italian early childhood. In L. Gandini and C. Edwards (Eds.), Bambini: Infant-toddler centers in Italy, pp. 200-215. NY: Teachers College Press.

New, R. (1999b). "What should children learn? Making choices and taking chances." Early Childhood Research and Practice, 1,(2), 1-25. www.eric.org/ecrp.

New, R. (1998). Theory and praxis in Reggio Emilia: They know what they are doing and why. In C. Edwards, L. Gandini, \& G. Forman (Eds.), The hundred languages of children: Reggio Emilia approach to early childhood education. $2^{\text {nd }}$ edition, $\mathrm{pp}$. Norwood, NJ: Ablex.

New, R. (1991). Early childhood teacher education in Italy: Reggio Emilia's master plan for "master" teachers. The Journal of Early Childhood Teacher Education, 12(37), 3.

New, R. (1990). Excellent early education: A city in Italy has it! Young Children, 45, 4-10.

New, R. (1988). Parental goals and Italian infant care. In R.A. LeVine, P.M. Miller, and M.M. West (Eds.), Parental Behavior in Diverse Societies. New Directions for Child Development, no. 40, 51-64. San Francisco, CA: Jossey-Bass.

New, R., \& Kantor, R. (2013). Reggio Emilia in the 21st Century: Enduring commitments, new challenges. In J. Roopnarine and J. Johnson (Eds.), Approaches to early childhood education, 6th edition, pp. 331-354. Boston: Pearson..

New, R., \& Mallory, B. (2005). Children as catalysts for adult relations: New partnerships in home-school-community relations in Italian early childhood education. In O.Saracho \& B.Spodek (eds.) Contemporary Perspectives in Early Childhood Education Families \& Communities

New, R., \& Mallory, B. (1996). The paradox of diversity in early care and education. In E. J. Erwin (Ed.), Putting children first: Visions for a brighter future for young children and their families (pp. 143-167). Baltimore: Paul H. Brookes.

New, R., Mallory, B. \& Mantovani, S. (2000). Cultural images of children, parents, and teachers: Italian home-school relations Early Education and Development, 11(5), $97-$ 616. 
New, R., Mardell, B., \& Robinson, D. (2005). Early childhood education as risky business: Going beyond what's "safe" to discovering what's possible . Early Childhood Research to Practice, Vol. 7 (2). Online journal. http://ecrp.uiuc.edu/v7n2/new.html

NICHD Early Child Care Research Network (2018). Study Overview. Washington DC. National Institute of Child Health and Human Development. https://www.nichd.nih.gov/research/supported/seccyd/overview

Nitecki, E. \& Wasmuth, H. (2017). Global trends in early childhood practice: Working within the limitations of the global education reform movement. Introduction to Global Education Review: Global Trends in Early Childhood Practice, 4 (3), 1-13.

OECD (2001, 2006) Starting Strong: early childhood education and care, vols. I and II, Paris, Author.

Rogoff, B. (2003). The cultural nature of human development. Oxford: Oxford University Press.

Roopnarine and Johnson, J. (Eds.) (2013). Approaches to Early Childhood Education, 6th Edition. Boston, MA: Pearson.

Sahin, B. K., Sak, R. \& Sahin, I. T. (2013). Parents' views about preschool education. Procedia - Social and Behavioral Sciences, 89, 288 - 292

Sak, R. (2015). Comparison of self-efficacy between male and female pre-service early childhood teachers. Early Child Development and Care, 185(10), 1629-1640. Doi: 10.1080/03004430.2015.1014353 (ERIC)

Saraceno, C. (1984). The social construction of childhood: Child care and education policies in Italy and the United States. Social Problems, 31 (3), 351-363.

Suárez-Orozco, C., Suárez-Orozco, M., \& Todorova, I. (2008). Learning a new land: Immigrant students in American society. Cambridge, MA: Harvard University Press.

Super, C., \& Harkness, S. (1986). The developmental niche. New Directions for Child Development (8). San Francisco, CA: Jossey-Bass.

Tobin, J., Hsueh, Y., \& Karasawa, M. (2009), Preschools in Three Cultures Revisited. University of Chicago Press, 2009.

Tobin, J., Wu, Y. H., Davidson, D. (1989). Preschools in three cultures: Japan, China and the U.S. New Haven, CT: Yale University Press.

Weisner, T. (1996). Why ethnography should be the most important method in the study of human development. In R. Jessor, A. Colby \& R. Shweder (Eds.), Ethnography and Human Development. Chicago: University of Chicago Press.

Zong, Jie \& Batalova, Jeanne. (2017). Frequently requested statistics on immigrants and immigration in the United States. Migration Policy Source [online journal] Spotlight March 8 2017. Washington, DC: Migration Policy Institute.

https://www.migrationpolicy.org/article/frequently-requested-statistics-immigrantsand-immigration-united-states 